\title{
Agricultural Sustainability at Farm Level: A Comparative Analysis of Rainfed and Irrigated Farmers in North Eastern Karnataka Region
}

\author{
Devendra Beeraladinni $^{1 *}$, B. L. Patil ${ }^{1}$, Jagrati Deshmanya ${ }^{2}$, \\ R. S. Poddar ${ }^{3}$, K. V. Ashalatha ${ }^{4}$ and J. S. Sonnad ${ }^{5}$ \\ ${ }^{1}$ Department of Agricultural Economics, College of Agriculture, UAS, \\ Dharwad-580005, Karnataka, India \\ ${ }^{2}$ Department of Agricultural Economics, College of Agriculture, UAS, \\ Raichur-5841004, Karnataka, India \\ ${ }^{3}$ Land and Water Management Institute (WALMI), Dharwad-580011, Karnataka, India \\ ${ }^{4}$ Department of Agricultural Statistics, ${ }^{5}$ Department of Agribusiness Management, College of \\ Agriculture, UAS, Dharwad-580005, Karnataka, India \\ *Corresponding author
}

\section{A B S T R A C T}

\section{Keywords}

Economically sustainable farming practices, Expected score, Farmers sustainability Index (FSI), North Eastern Karnataka

\section{Article Info}

Accepted: 18 July 2020 Available Online: 10 August 2020
The present study assessed the status of farm level agricultural sustainability for rainfed and irrigated farmers in Raichur and Yadgir districts of North Eastern Karnataka by constructing Farmers Sustainability Index (FSI) encompassing four component indicators of farm level sustainability viz., Economically sustainable farming practices, Environmentally sustainable farming practices, Sustainable crop production practices and Socio economic factors. The primary data on 33 variables was collected from the 240 farmers which comprised 120 irrigated and 120 rainfed farmers. The results of the study showed that in both the districts majority of the rainfed farmers 45 per cent in Raichur and 55 per cent in Yadgir were sustainable compared to irrigated farmers where 70 per cent in Yadigr district and about 53 per cent in Raichur district comes under unsustainable category. In irrigated area the actual mean score of the three components of farm level agricultural sustainability were above the expected mean score except for the component environmentally sustainable farming practices ( 0.49 in Raichur district and 0.44 in Yadgir district ) which was lower than the expected mean score (0.60). However, in rainfed area the actual mean scores of all the components were above the expected average score, as majority of rainfed farmers fallowed economically and environmentally sustainable farming practices such as crop rotation, crop diversification, mixed and intercropping, application of farm yard manures, agronomic method of plant protection and cultural method of weed management. There is a need to promote the sustainable farming practices such as judicial use of fertilizers and plant protection chemicals, adaption of efficient water use techniques and Integrated Pest Management techniques, use of organic manures and diversification of farm activities in the irrigated areas of both the districts. In addition, educating the farmers about agricultural sustainability and resource conservation will improve the agricultural sustainability of farmers at farm level in North Eastern Karnataka region. 


\section{Introduction}

Individual farm level agricultural sustainability is crucial in the courtiers where large proportion of the population depends on agriculture and operates smaller holdings for livelihood. India is an agricultural country and more than 80 per cent of farmers are small and marginal who own less than five acres of land and play a key role in ensuring food security hence it is vital to see that these section of farming community needs to be sustainable economically, environmentally and socially. Agricultural sustainability at farm level entail continuous farm income in long run without harming the environment and enhancing the productive capacity of the soil by fallowing economically viable and environmentally sustainable farming practices. At the farm level, an agriculture system is sustainable when it is possible to produce crop and livestock products based on scientific innovations that encompass land, water, farmer's health and rights without compromising the yield levels. The basic principles of agricultural sustainability at farm level include producing healthy food, improve the quality of environment, maintaining the natural resource base, use of non-renewable and on farm resources in most effective way, implement the natural biological cycles, support rural economic development as well as the quality of farmer's life (EOS, 2019). The concept of agricultural sustainability at farm level involves the identification of resource limitations and minimising the use of resources that harm the environment and using the knowledge and skill (Jules Pretty, 2007). At farm level sustainability can be defined as farming systems that are capable of resource conserving, socially supportive, commercially competitive, and environmentally sound (Gold, 2007). Another definition of sustainable agriculture at farm level was given in U.S. Code (Title 7, section 3103) as an integrated system of plant and animal production practices having a site specific application that will over the long term satisfy human food and fibre needs; enhance environmental quality and the natural resource base; make the most efficient use of non-renewable sources and on farm resources and integrate where appropriate, natural biological source and controls; sustain the economic viability of the farm operations and improve livelihood of farmers and society as a whole.

Agriculture must be environmentally sound, economically feasible, socially scrupulous and flexible (for future needs). Optimizing the use of locally available resources, thereby achieving a synergetic effect among the various components of the farming system (soil, water, animals, plants, etc.) so that they complement each other in the production system and minimizing the use of external inputs, except where there is a serious deficiency and where the effect on the system will be to increase recycling of nutrients. Sustainable is not a call for going back to farming practices that forced farmers to practice subsistence farming systems. However, it is to guide them toward the right ways of practicing farming and adopting new agricultural innovations for maximum benefits while saving the environment for the future generations (Rika Terano, 2014) as sustainable agriculture is a set of agronomic practices that are economically viable, environmentally safe and socially acceptable. Of late, the indiscriminate use of fertilizers and pesticides, deforestation and urbanisation led to increased awareness of sustainable farming practices in place of input intensive agriculture system. Hence, recycling of nutrients, improving efficiencies of fertilizer applications, usage of organic nutrient sources (animal and green manures) are important elements of that ensure the sustainability at farm level. Recycling of nutrients is facilitated by a diversified agriculture in 
which livestock and crop production are more spatially integrated (Brodt et.al., 2011). In India to achieve the sustainable development in agriculture at district level the Central Government in January 2018 launched Transformation of Aspirational Districts Initiative in 101 most backward districts in the country. NITI Aayog in 2018 identified 101 districts as aspirational districts among which two districts Raichur (rank 12) and Yadgir (rank 40) from North Eastern Karnataka region of the state were included. The aspirational districts were given base line rank based on 49 indicators from the five area, health and nutrition, education, agriculture and water resources, basic infrastructure, financial inclusion and skill development. Raichur district scored 43.53 per cent on various development indicators whereas; Yadgir district scored 37.1 per cent as these two districts have performed poor in 49 indicators (NITI Aayog, 2018). In light of these developments this study examined the agricultural sustainability at farm level by constructing agricultural sustainability index for the rainfed and irrigated farmers of these two districts.

\section{Materials and Methods}

Two districts viz., Raichur and Yadgir of North Eastern Karnataka region were selected to analyse the agriculture sustainability at farm level. Two taluks (Rainfed and Irrigated) from each district were selected based on the highest and lowest area under irrigation. Accordingly, Sidhanur taluk which has highest irrigated area and Raichur taluk which has lowest irrigated area were selected from Raichur district. Similarly, Shahpur taluk which has highest irrigated area and Yadgir taluk which has lowest irrigated area selected from Yadgir district. Three villages were selected from each taluk and 20 farmers were selected randomly from each village. Thus the total sample size for this study was 240 farmers which comprised 120 irrigated farmers and 120 rainfed farmers. The primary data on socio-economic status, size of land holdings, farm asset position, livestock possession, source of non farm income, cropping pattern, crop wise organic and inorganic input use pattern, sustainable farming practices fallowed, adaption of sustainable crop production methods, problems faced to adapt sustainable farming practices, costs and returns, and change in use of plant protection chemicals, organic and inorganic inputs was collected from selected 240 sample farmers. In addition the expert opinion survey was conducted to assign the weights to the various components of Farmers Sustainability Index (FSI). Thirty scientists were asked to assign the scores to the various components as detailed in the Table 2

Agricultural sustainability Index at farm level was constructed by selecting thirty three variables and these variables were grouped under four components viz., economically sustainable farming practices, environmentally sustainable farming practices, Sustainable crop production practices and Socio economic factors. The variables grouped under each component were assigned a simple score based on the criteria commonly adapted for measuring agricultural sustainability at farm level. In this study, the method of scoring is adapted from the past studies (Rigby et al., 2001; Lawal et al., 2011; Sharma and Shardendu, 2011; Terana and Mohamed, 2015; Hannah, 2015) and employed with slight modifications. The scoring of variables depicted in Table 1 is illustrated in their respective headings.

\section{Economically sustainable farming practices}

The variables considered under this component enhance the income and reduces the cost of production at individual farm. Eight practices viz., usage of farm yard 
manure, sheep penning/sheep manure application, Crop diversification, Use of alternative crop in succeeding season, crop rotation, Aquaculture/Poultry/Dairy/silkworm rearing, Mixed cropping/ Intercropping and use of indigenous technological knowledge were considered in this component and 0 score was assigned when a practice was not followed by the sample farmer, 1 was assigned if the practice was followed from one year, 2 was assigned if the practice was followed from 5 years and 3 was assigned if the practice was followed from more than 5 years. Each of the eight variable has a maximum score of 3 thus the total expected score for this component is 48 for irrigated farmers and 42 for rainfed farmers and 13.75 and 15.71 are weighted scores for rainfed and irrigated farmers respectively (Table 2).

\section{Environmentally sustainable farming practices}

The variables which were considered under this component improve the ecological environment of the farm business. The eight practices such as conservation tillage, green manuring/ mulching, Bio fertilizer application, vermin compost application, Integrated Pest Management (IPM), Integrated Nutrient Management (INM), Agro forestry/ Beekeeping, Soil erosion control measures (Bund farming/tree planting/cover crop) improves the environmental quality and ecosystem. The scoring scheme for this component is same as in case of economically sustainable farming practices. 0 score was assigned when the respective practice was not fallowed, 1 was assigned if the practice was fallowed from one year, 2 was assigned if the practice was fallowed from 5 years and 3 was assigned if the practice was fallowed from more than 5 years from the sample farmers. Each of the eight variables has a maximum score of 3 thus the total expected score in this component is 48 for both rainfed and irrigated farmers. The weighted score is 14.58 .

\section{Sustainable crop production practices}

The variables considered under this component are crop production practices which are economically efficient and environmentally sustainable. This component was measured by selecting the eight practices namely Land preparation (mechanical or non mechanical), Sowing (mechanical or non mechanical), Seed treatment (fallowed or not fallowed), Irrigation (flooding, ridge and furrow, sprinkler, drip), Inter cultivation (one time, two time, more than two times), Weed management (cultural method, chemical method, physical method), Plant protection (Chemical method, biological method, agronomic method) and Chemical fertilizers use (more than recommended, less than recommended, recommended). Each practices considered under this component were assigned the score 0 to 4 . 0 score indicates no significant impact or negative impact on farm sustainability, 1 indicates marginal positive impact, 2 indicates positive significant impact, 3 indicates positive strong impact and 4 indicates very strong positive significant impact on sustainability of a farm.

The score for each production practice was assigned accordingly, for instances in case of seed treatment when the farmer not fallowed seed treatment 0 score was assigned and the farmer who fallowed seed treatment received score 1 to indicate the impact of seed treatment on crop yield. Similarly in case of weed management the sample farmer who fallowed cultural method received score 2 , the farmer who fallowed physical method received score 3 and the farmer fallowed chemical method received score 1 to indicate the impact of these methods on sustainability of the farm. The total expected score for this component is 33 for rainfed farmers and 43 for irrigated farmers. Whereas weighted scores are 6.75 (rainfed) and 8.80 (irrigated). 


\section{Socio economic factors}

Scio-economic factors such as farmers Age, Education, Family members, Non farm income, Farm size, Livestock possession, Net farm income, Farming experience, Sale of produce etc., influences the farm level agricultural sustainability for instance educated farmer easily adapt the farming practices which are sustainable. Eight socioeconomic aspects were considered and scores were assigned to each variable as given in the Table 1. Each aspects considered under this component were assigned the score 0 to 3.0 score indicates no significant impact or negative impact on farm sustainability, 1 indicates marginal positive impact, 2 indicate positive significant impact, 3 indicate positive strong impact on sustainability of a farm. The score for each socio-economic factors was assigned accordingly, for instances in case of education if the sample farmer was not attended school 0 score was assigned and when the farmer has the education of primary or high school level score 1 was assigned and when the farmer has the education level of college and above score 2 was assigned to indicate the impact of education on farm performance. Similarly in case of livestock possession when a sample farmer not owned farm animals score 0 was assigned, when the farmer owned 1-3 animals score 2 was assigned and when the farmed owned more than 3 farm animals score 3 was assigned to indicate the contribution of livestock to sustainability of the farm. Thus the total expected score for this component is 42 and weighted score is 6.90 for both rainfed and irrigated farmers.

The total actual score for each farmer was arrived at by adding all the scores that a farmer received for each individual variable that constituted the actual un weighted score. The indexing process should be followed by the weighting procedure in which all the stakeholders conditioning the sustainability of a system are called to rank indicators and levels according to the perceived relevance (Migliorini et al., 2018). Therefore, weights were assigned to each component based on the results of opinion survey conducted for this purpose. In order to assign the weights to all the four components and to validate the scores an experts opinion survey was conducted by circulating the proposed schedule of scoring scheme among the 30 scientists working in agricultural universities and the scientists were asked to assign score to each component (maximum 100 for all the components together) in the order of most influencing component for farm level sustainability.

The results of the experts opinion survey is presented in Table 2. In addition adjustment was made on the individual variable scores as suggested by the experts. To measure the individual components, expected total scores of each component were compared with actual scores obtained by the farmers and presented with radar diagrams. The experts were asked to assign scores to each component. A score out of 100 has to allot to four components considering the importance of each component in improving the farm level agricultural sustainability. Accordingly the experts assigned highest score of 982 to the economically sustainable farming practices and lowest score of 493 to the socioeconomic factors. Environmentally sustainable practices scored 911 and sustainable farming practices scores 614 by the experts. The total score assigned for all the components together was 3000 . Based on this weightage for each component was estimated by taking the percentage of individual component scores to the total score. Thus the weights were $32.73,30.37$, 20.47 and 16.43 for all four components viz., economically sustainable farming practices, environmentally sustainable farming 
practices, sustainable crop production practices and socioeconomic factors respectively

\section{Analytical framework}

The agricultural sustainability index was computed using weighted scores obtained from the four components, namely economically sustainable farming practices, environmentally sustainable farming practices, Sustainable crop production practices and Socio economic factors as detailed below. Each of these components can take account of the various dimensions of sustainability separately, or they can encapsulate all these components in frameworks of indicators.

The various components or indicators can be combined to arrive at one component or indicator for each of the dimensions of sustainability, for example one economic, one social, one innovation and one environmental indicator per farm. It is also possible to aggregate all of these indicators so as to arrive at one composite measure of farm-level sustainability for each farm (Ryan et al., 2014). The scores were assigned to each variable for all individual farmers as per the scoring scheme developed (Table 1) and the score of individual component for each sample farmer was obtained by adding the scores of all the variables as scored by individual farmer.

$\mathrm{Cj}=\sum_{i=1}^{n} \mathrm{Xik}$,

Where

$\mathrm{X}_{\mathrm{ik}}=\mathrm{i}^{\text {th }}$ Variable in each component for $\mathrm{k}^{\text {th }}$ farmer, $\mathrm{i}=1$.........n

$\mathrm{C}_{\mathrm{j}}=\mathrm{j}^{\text {th }}$ Component value, $\mathrm{j}=1 \ldots 4$

The method of 'summing of scores' allows full compensation between the component variables, which may be sensible where variables are related and allows some values to offset others as full compensation between values is permitted when the value for each variable is summed to produce an aggregate value (Frater and Franks, 2013). To overcome the problem of score aggregation, the weights were assigned to each component based on the expert's opinion survey results to the total score of individual components to obtain the weighted scores. This can be written as

$\mathrm{W}_{\mathrm{j}} \mathrm{C}_{\mathrm{j}}=\mathrm{W}_{\mathrm{j}}^{\sum_{i=1}^{n} \mathrm{Xik}}$

Where $\mathrm{W}_{\mathrm{j}}$ is the weight assigned to $\mathrm{j}^{\text {th }}$ component

The weighted score of each component were added for each individual farmer to obtain the total weighted score

Total weighted score $\left(\mathrm{W}_{\mathrm{k}}\right)=\sum_{j=1}^{4} \mathrm{WjCj}_{\mathrm{j}}$ $\mathrm{k}=1$........60

The total weighted scores of all the farmers were transformed to 0 to 100 scale score using the following expression.

Let $\mathrm{FSI}_{\mathrm{k}}$ (Farmers Sustainability Index) be the transformed score value of $\mathrm{k}^{\text {th }}$ farmer and $\mathrm{W}_{\mathrm{k}}$ be the total weighted score of $k^{\text {th }}$ farmer. This can be expressed as

$F S I k=\frac{W k-M i n W k}{\text { MaxWk }- \text { MinWk }} * 100 \ldots \ldots \ldots \ldots \ldots .1$

Where,

$\mathrm{k}=$ Sample Farmer $(1,2,3 \ldots \ldots . .60)$

$\mathrm{W}_{\mathrm{k}}=$ Total weighted Score of $\mathrm{k}^{\text {th }}$ farmer $\mathrm{MaxW}_{\mathrm{k}}=$ Maximum Score of $\mathrm{k}^{\text {th }}$ farmer $\operatorname{MinW}_{\mathrm{k}}=$ Minimum score of $\mathrm{k}^{\text {th }}$ farmer $\mathrm{FSI}_{\mathrm{k}}=$ Sustainability Index of $\mathrm{k}^{\text {th }}$ farmer

FSI values which were calculated using the equation (1) lies between 0 to 100 , if FSI is 
near to 100 that indicates better performance of the farmer and if FSI value is near to zero indicates poor performance of the farmer with respect farm level sustainability. After testing the normality of FSI values, the farmers were grouped into three categories of agriculture sustainability as mentioned below. Let $\bar{X}=$ Mean of FSI, $\sigma=$ Standard deviation of FSI

1. Less than $(\bar{X}-0.425 \sigma)$ : Unsustainable 2. $(\bar{X}-0.425 \sigma)$ to $(\bar{X}+0.425 \sigma)$ : Somewhat sustainable

3. Above $(\bar{X}+0.425 \sigma)$ : Sustainable

\section{Results and Discussion}

The Farmers Sustainability Index (FSI) for the two districts of North Eastern Karnataka is presented in Table 3. Based on the values of Farmers Sustainability Index the sample irrigated and rainfed farmers of Raichur and Yadgir districts were grouped into unsustainable, somewhat sustainable and sustainable categories.

The results of the study revealed that about 53.33 per cent irrigated farmers in Raichur district were unsustainable whereas 45 per cent of the rainfed famers were sustainable and 8.34 per cent of irrigated farmers and 16.67 farmers of rainfed farmers were categorised as somewhat sustainable. Similarly in Yadgir district only 20 per cent of the irrigated farmers and about 55 per cent of rainfed farmers comes under sustainable category. About 70 per cent of the irrigated farmers were unsustainable and about 21 per cent of rainfed farmers were unsustainable. Remaining 10 per cent of irrigated farmers and 23.33 per cent of rainfed farmers belonged to somewhat sustainable category. Majority of the irrigated farmers in Yadgir and Raichur district were unsustainable compared to rainfed farmers due to the reason that low yields, small size of land holding and most important reason was the farmers were not fallowing the Integrated pest management, green manuring and lack of crop diversification. Similar study was conducted by Prem Chand et al., (2015) where Sustainable Dairy Farming Index (SDFI) was constructed the results revealed that 65 per cent dairy farmers had low level sustainability, 29.2 per cent had moderate level of sustainability and 5.8 per cent had high level of sustainability. Another study conducted by Terano et al., (2015) examined the degree of sustainability at farm level in Malaysia by constructing paddy farmers sustainability index (PFSI).

The results showed that out of 60 farmers, only six $(9.8 \%)$ were at the level of somewhat sustainable and none of them were possibly very unsustainable nor they were sustainable. Hannah (2015) also constructed agricultural sustainability index with reference to rice production in MADA, Malaysia.

The results of agricultural sustainability index value revealed that 92.5 per cent of the farmers were sustainable while 7.46 per cent were unsustainable in their production system and the farmers who practiced sustainable production system were those with smaller farm size.

The individual components were measured by comparing the expected total scores of each component with actual scores obtained by the farmers and presented with radar diagrams. Each spine of the radar diagram calibrated from zero at the origin to highest percentage of index weight farthest from its origin, farther the web is to the origin the better the categories with the FSI.

The four components represent the different proportion in the total score which indicate the contribution of each component in 
calculating the FSI. The proportion of each component in the farm level sustainability, actual mean scores and expected mean scores are depicted in Table 4 and Fig. 1-4. In irrigated area the actual mean scores of components economically sustainable farming practices (2.72 in Raichur district and 1.94 in Yadgir district), Sustainable crop production methods (2.25 in Raichur district and 2.40 in Yadgir district) and socio economic factors (2.20 in Raichur district and 2.57 in Yadgir district) were above the expected average score in irrigated conditions.

Whereas, the actual mean score in the component environmentally sustainable farming practices (0.49 in Raichur district and 0.44 in Yadgir district) was lower than the average of the expected scoring (0.60). This result implies that the majority of irrigated farmers in the study area not fallowed environmentally sustainable farming practices. However, in rainfed area the actual mean scores of all the components viz., economically sustainable farming practices (2.67 in Raichur district and 3.28 in Yadgir district), environmentally sustainable farming practices (1.40 in Raichur district and 2.75 in Yadgir district), sustainable crop production methods (2.21 in Raichur district and 2.63 in Yadgir district) and socio economic factors (2.08 in Raichur district and 2.31 in Yadgir district) were above the expected average score of $0.66,0.60,0.34$ and 0.26 for economically sustainable farming practices, environmentally sustainable farming practices, sustainable crop production methods and socio economic factors respectively.

Table.1 Scoring scheme of variables under different components of farm level sustainability

\section{Components and variables}

\section{Economically sustainable farming practices}

1. Usage of farm yard manure

2. Sheep penning/sheep manure application

3. Crop diversification

4. Use of alternative crop in succeeding season

5. Crop rotation

6. Aquaculture/ Poultry/ Dairy/ silkworm rearing

7. Mixed cropping/ Intercropping

8. Use of Indigenous technological knowledge

II. Environmentally sustainable farming practices

1. Conservation tillage

2. Green manuring/mulching

3. Bio fertilizer application

4. Vermicompost application

5. Integrated pest management (IPM)

6. Integrated nutrient management (INM)

7. Agro forestry/ Beekeeping

8. Soil erosion control measures (Bund farming/tree planting/cover crop)

\section{Score}

Not fallowed $=0$

Following from $<1$ year $=1$

$1-5$ years $=2$

$>5$ years $=3$

Total Score $=48$
Not fallowed $=0$

Following from $<1$ year $=1$

$1-5$ years $=2$

$>5$ years $=3$

Total Score $=48$ 


\section{III.Sustainable crop production practices}

\section{Land preparation}

2. Sowing

3. Seed treatment

4. Irrigation

5. Intercultivation

6. Weed management

7. Plant protection

8. Chemical fertilizers use

\section{Socio economic factors}

\section{Age}

2. Education

3. Adult Family members
Non Mechanized=1

Mechanized $=2$

Non Mechanized=1

Mechanized=2

Yes $=1$

$\mathrm{No}=0$

Flood $=1$

Ridge and Furrow $=2$

Sprinkler $=3$

Drip $=4$

One time $=1$

Two times $=2$

$>$ Two times $=3$

Chemical method $=1$

Cultural method $=2$

Physical method $=3$

Chemical $=1$

Biological $=2$

Agronomic $=3$

More than recommended $=$

1

Less than recommended $=2$

Recommended $=3$

Total Score $=43$

$>55$ years $=1$

$46-55$ years $=225-45$

years $=3$

Never attended school $=0$

Primary and high school $=$ 1

Collegiate and above $=2$

Up to $5=1$

$>5=2$ 


\section{Non farm income per year}

\section{Farm size}

$$
\begin{aligned}
& \text { Nil }=0 \\
& <50000=1 \\
& 50000 \text { to } 100000=2 \\
& >100000=3 \\
& <2 \text { hectors }=1 \\
& 2 \text { ha to } 4 \text { ha }=2 \\
& >4 \text { ha }=3 \\
& \text { Not owned }=0 \\
& 1-3 \text { animals }=1 \\
& >3 \text { animals }=2 \\
& <100000=1 \\
& 100000 \text { to } 200000=2 \\
& >200000=3 \\
& <15 \text { years }=1 \\
& 15 \text { to } 25 \text { years }=2 \\
& >25 \text { years }=3 \\
& \text { Village sales }=1 \\
& \text { APMC sales }=2 \\
& \text { Total score }=\mathbf{4 2}
\end{aligned}
$$

\begin{tabular}{|c|c|c|c|c|c|c|}
\hline \multirow[b]{2}{*}{ Sl.No } & \multirow[b]{2}{*}{ Particulaurs } & \multicolumn{4}{|c|}{ Sustainability components } & \multirow[b]{2}{*}{$\begin{array}{l}\text { Total } \\
\text { score }\end{array}$} \\
\hline & & $\begin{array}{c}\text { Economically } \\
\text { sustainable farming } \\
\text { practices }\end{array}$ & $\begin{array}{c}\text { Environmentally } \\
\text { sustainable farming } \\
\text { practices }\end{array}$ & $\begin{array}{c}\text { Sustainable crop } \\
\text { production } \\
\text { practices }\end{array}$ & $\begin{array}{l}\text { Socio } \\
\text { economic } \\
\text { factors }\end{array}$ & \\
\hline 1 & $\begin{array}{l}\text { Scores assigned by } \\
\text { experts }(n=30)\end{array}$ & 982 & 911 & 614 & 493 & 3000 \\
\hline 2 & Weights & 32.73 & 30.37 & 20.47 & 16.43 & - \\
\hline 3 & $\begin{array}{l}\text { Unweighted Score } \\
\text { Rainfed } \\
\text { Irrigated }\end{array}$ & $\begin{array}{l}42(26) \\
48(26)\end{array}$ & $\begin{array}{l}48(29) \\
48(27)\end{array}$ & $\begin{array}{l}33(20) \\
43(24)\end{array}$ & $\begin{array}{l}42(25) \\
42(23)\end{array}$ & $\begin{array}{l}165 \\
181\end{array}$ \\
\hline 4 & $\begin{array}{l}\text { Weighted score } \\
\text { Rainfed } \\
\text { Irrigated }\end{array}$ & $\begin{array}{l}13.75(33) \\
15.71(34)\end{array}$ & $\begin{array}{l}14.58(35) \\
14.58(32)\end{array}$ & $\begin{array}{l}6.75(16) \\
8.80(19)\end{array}$ & $\begin{array}{l}6.90(16) \\
6.90(15)\end{array}$ & $\begin{array}{l}41.98 \\
45.99\end{array}$ \\
\hline
\end{tabular}

6. Livestock possession

7. Net farm income per year

Note: $6^{\text {th }}$ variable in component I and $4^{\text {th }}$ variable in component III is not applicable to raifned situation

Table.2 Weigthed and unweighted scores of different components of farm level agricultural sustainability (experts opinion survey)

Note: Figures in parenthesis indicate contribution of individual component to the farm level agricultural sustainability 
Table.3 Classification of sample farmers based on FSI values under rainfed and irrigated farming in Raichur and Yadgir districts

\begin{tabular}{|c|c|c|c|c|c|}
\hline \multicolumn{6}{|l|}{ Raichur } \\
\hline \multirow{2}{*}{$\begin{array}{c}\text { FSI } \\
\text { value }\end{array}$} & \multirow{2}{*}{$\begin{array}{c}\text { Sustainability } \\
\text { criteria }\end{array}$} & \multicolumn{2}{|c|}{ Rainfed $(n=120)$} & \multicolumn{2}{|c|}{ Irrigated $(n=120)$} \\
\hline & & No of farmers & Per cent & No of farmers & Per cent \\
\hline 0-37 & Unsustainable & 23 & 38.33 & 32 & 53.33 \\
\hline $38-61$ & $\begin{array}{l}\text { Somewhat } \\
\text { Sustainable }\end{array}$ & 10 & 16.67 & 5 & 8.34 \\
\hline $62-100$ & Sustainable & 27 & 45.00 & 23 & 38.33 \\
\hline \multicolumn{6}{|l|}{ Yadgir } \\
\hline $0-37$ & Unsustainable & 13 & 21.67 & 42 & 70.00 \\
\hline $38-61$ & $\begin{array}{l}\text { Somewhat } \\
\text { Sustainable }\end{array}$ & 14 & 23.33 & 6 & 10.00 \\
\hline $62-100$ & Sustainable & 33 & 55.00 & 12 & 20.00 \\
\hline
\end{tabular}

Table.4 Expected and actual values of farm level agricultural sustainability components in Raichur and Yadgir districts

\begin{tabular}{|c|c|c|c|c|c|c|}
\hline \multirow[t]{2}{*}{ District } & \multirow{2}{*}{$\begin{array}{l}\text { Type of } \\
\text { farming }\end{array}$} & \multirow[t]{2}{*}{ Score } & \multicolumn{4}{|c|}{ Components of sustainability } \\
\hline & & & $\begin{array}{c}\text { Economically } \\
\text { sustainable farming } \\
\text { practices }\end{array}$ & $\begin{array}{c}\text { Environmentally } \\
\text { sustainable farming } \\
\text { practices }\end{array}$ & $\begin{array}{l}\text { Sustainable crop } \\
\text { production } \\
\text { methods }\end{array}$ & $\begin{array}{c}\text { Socio } \\
\text { economic } \\
\text { factors }\end{array}$ \\
\hline \multirow[t]{6}{*}{ Raichur } & \multirow[t]{3}{*}{ Irrigated } & $\begin{array}{l}\text { Expected total } \\
\text { score }\end{array}$ & 15.71 & 14.58 & 8.80 & 6.90 \\
\hline & & $\begin{array}{l}\text { Expected } \\
\text { mean score }\end{array}$ & 0.66 & 0.60 & 0.37 & 0.26 \\
\hline & & $\begin{array}{l}\text { Actual mean } \\
\text { score }\end{array}$ & $\begin{array}{c}2.72 \\
(17.17)\end{array}$ & $\begin{array}{c}0.49 \\
(3.40)\end{array}$ & $\begin{array}{c}2.25 \\
(26.16)\end{array}$ & $\begin{array}{c}2.20 \\
(32.74)\end{array}$ \\
\hline & \multirow[t]{3}{*}{ Rainfed } & $\begin{array}{l}\text { Expected total } \\
\text { score }\end{array}$ & 13.75 & 14.58 & 6.75 & 6.90 \\
\hline & & $\begin{array}{l}\text { Expected } \\
\text { mean score }\end{array}$ & 0.66 & 0.60 & 0.34 & 0.26 \\
\hline & & $\begin{array}{l}\text { Actual mean } \\
\text { score }\end{array}$ & $\begin{array}{c}2.67 \\
(19.26)\end{array}$ & $\begin{array}{l}1.40 \\
(9.72)\end{array}$ & $\begin{array}{c}2.21 \\
(33.48)\end{array}$ & $\begin{array}{c}2.08 \\
(30.95)\end{array}$ \\
\hline \multirow[t]{6}{*}{ Yadgir } & \multirow[t]{3}{*}{ Irrigated } & $\begin{array}{l}\text { Expected total } \\
\text { score }\end{array}$ & 15.71 & 14.58 & 8.80 & 6.90 \\
\hline & & $\begin{array}{l}\text { Expected } \\
\text { mean score }\end{array}$ & 0.66 & 0.60 & 0.37 & 0.26 \\
\hline & & $\begin{array}{l}\text { Actual mean } \\
\text { score }\end{array}$ & $\begin{array}{c}1.94 \\
(12.25)\end{array}$ & $\begin{array}{c}0.44 \\
(3.05)\end{array}$ & $\begin{array}{c}2.40 \\
(27.90)\end{array}$ & $\begin{array}{c}2.57 \\
(38.24)\end{array}$ \\
\hline & \multirow[t]{3}{*}{ Rainfed } & $\begin{array}{l}\text { Expected total } \\
\text { score }\end{array}$ & 13.75 & 14.58 & 6.75 & 6.90 \\
\hline & & $\begin{array}{l}\text { Expected } \\
\text { mean score }\end{array}$ & 0.66 & 0.60 & 0.34 & 0.26 \\
\hline & & $\begin{array}{l}\text { Actual mean } \\
\text { score }\end{array}$ & $\begin{array}{c}3.28 \\
(23.66)\end{array}$ & $\begin{array}{c}2.75 \\
(19.09)\end{array}$ & $\begin{array}{c}2.63 \\
(39.85)\end{array}$ & $\begin{array}{c}2.31 \\
(34.37)\end{array}$ \\
\hline
\end{tabular}

Note: Figures in parentheses indicate actual mean score as a per cent of expected score 
Int.J.Curr.Microbiol.App.Sci (2020) 9(8): 1704-1717
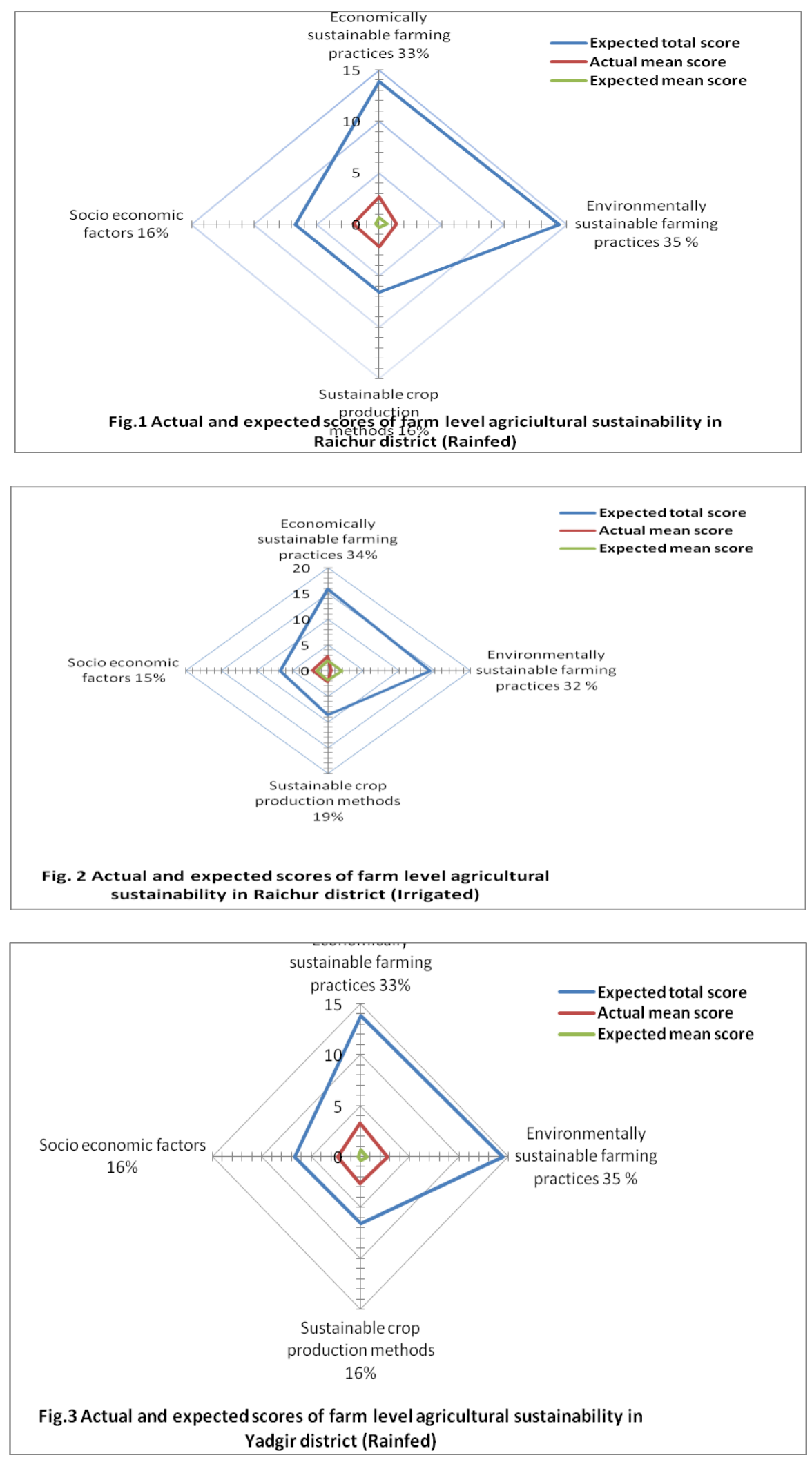


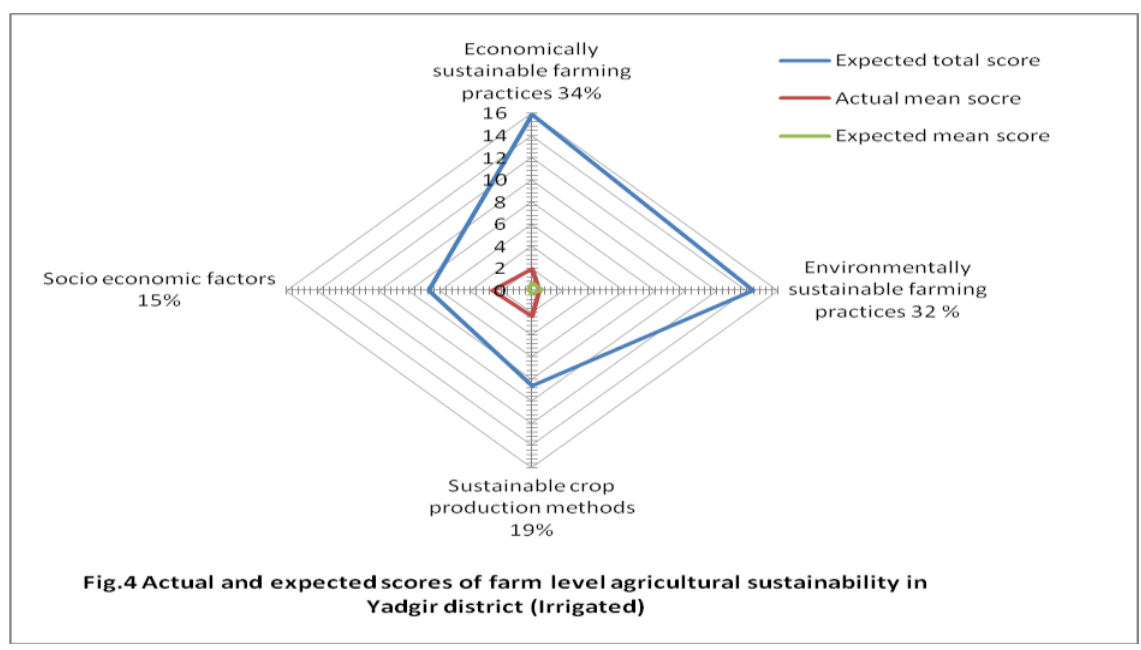

It is evident from the results that in both the districts majority of the irrigated sample farmers about 70 per cent in Yadgir district and about 53 per cent in Raichur district comes under unsustainable category this is attributed to the fact that majority of the irrigated farmers fallowed mono cropping and applied fertilizer more than recommended, no crop diversification, not fallowed integrated pest management or integrated nutrient management practices and used less quantity of farm yard manure and indiscriminate use of pesticides to manage weed, pest and diseases. The results of this study also revealed that in irrigated conditions the actual score of farm level agricultural sustainability in environmentally sustainable farming practices component was lower (o.44 in Yadgir district and 0.49 in Raichur district) compared to the expected score (0.60). Whereas, in rainfed area of both the districts majority of the farmers naturally fallow many economically and environmentally sustainable farming practices such as crop rotation, crop diversification, mixed and intercropping, application of farm yard manures, agronomic method of plant protection and cultural method of weed management. Based on the above findings, the following implications have been drawn to improve the agricultural sustainability of farmers at farm level in North Eastern Karnataka region. i) There is a need to promote the sustainable agricultural practices such as judicial use of fertilizers and plant protection chemicals, adaption of efficient water use techniques, use of organic manures and diversification of farm activities in the irrigated areas of both the district ii) Educate the farmers on the aspects of agricultural sustainability and resource conservation iii) Farmers need to be encouraged to adapt the Integrated Pest Management and Integrated Nutrient Management practices.

\section{References}

Anonymous, 2018, Transformation of aspirational districts: Base line ranking and real time monitoring dash board, NITI Ayog, Government of India. Pp-7.

Anonymous, 2019, Earth observing system, a digital online platform, retrieved on 22.07.2020 from https://eos.com/.

Ajidasile Oluwagbemisola Hannah, 2015, Creating agricultural sustainability index: the case of rice farmers in MADA, Malaysia. Canadian International Conference on Global Studies

Brodt, S., Six, J., Feenstra, G., Ingels, C. and Campbell, D., 2011, Sustainable Agriculture. Nature Education Knowledge, 3(10): 1-20 
Dan Rigby, Phil Woodhouse, Trevor Young and Michael Burton, 2001, Constructing a farm level indicator of sustainable agricultural practice. Ecological Economics, 39: 463-478

Deepti Sharma \& Shardendu Shardendu, 2011, Assessing farm-level agricultural sustainability over a 60 -year period in rural Eastern India. The Environmentalist, 31(3):325-337

Jules Pretty, 2008, Agricultural sustainability: concepts, principles and evidence. Phil. Trans. R. Soc. B. 363: 447-465

Lawal, A. F; Omotesho, O. A. and Adewumi, M.O., 2011, A farm level sustainability indicator for horticultural crop producers in FADAMA areas of Southern Guinea Savannah of Nigeria. Nigerian Journal of Agricultural Economics, 2(1):28 - 41

Mary Ryan1, Cathal Buckley, Emma Jane Dillon, Trevor Donnellan, Kevin Hanrahan, Thia Hennessy and Brian Moran, 2014, The development of farmlevel sustainability indicators for Ireland using the Teagasc National Farm Survey. 88th Annual Conference of the Agricultural Economics Society, AgroParisTech, Paris, France, 9 - 11 April 2014
Mary V. Gold, 2007, Sustainable Agriculture: Definitions and Terms Briefs Series no. SRB 99-02 National Agricultural Library retrieved on 22.07.2020 from www.nal.usda.gov/ afsic/sustainable

Paola Migliorini, Francesco Galioto, Massimo Chiorri and Concetta Vazzana, 2018, An integrated sustainability score based on agro-ecological and socioeconomic indicators. A case study of stockless organic farming in Italy. Agroecology and Sustainable Food Systems, 1-26

Poppy Frater1 and Jeremy Franks, 2013, Measuring agricultural sustainability at the farm-level: a pragmatic approach. International Journal of Agricultural Management, 2(4): 207-225

Prem Chand, Smita Sirohi \& Sirohi SK., 2015, Development and application of an integrated sustainability index for small-holder dairy farms in Rajasthan, India. Ecological Indicators, 56:23-30

Rika Terano, Zainalabidin Mohamed, Mad Nasir Shamsudin and Ismail Abd Latif, 2014, Farmers sustainability index: the case of paddy farmers in state of Kelantan, Malaysia. J. ISSAAS, 21(1): 55-67

\section{How to cite this article:}

Devendra Beeraladinni, B. L. Patil, Jagrati Deshmanya, R. S. Poddar, K. V Ashalatha and Sonnad, J. S. 2020. Agricultural Sustainability at Farm Level: A Comparative Analysis of Rainfed and Irrigated Farmers in North Eastern Karnataka Region. Int.J.Curr.Microbiol.App.Sci. 9(08): 1704-1717. doi: https://doi.org/10.20546/ijcmas.2020.908.196 